\title{
The Antecedents, Consequences, And Mediating Role Of Job Satisfaction: Perception And Relevance Among Civil Servants In Regional Government's Working Unit Selayar Islands District
}

\author{
1) Tajuddin Makka, ${ }^{2)}$ H. Murdifin Haming, ${ }^{3)}$ Baharuddin Semmaila, \\ 4) Ramlawati \\ Doctoral Student, University of Muslim Indonesia \\ 2, 3, 4) Faculty of Economics, University of Muslim Indonesia \\ Corresponding Author: Tajuddin Makka
}

\begin{abstract}
This study aims to examine and analyze the effect of competence, work culture and organizational commitment on job satisfaction and civil servants performance in regional government's working unit Selayar Islands District. The study was conducted on 4.321 civil servants. A total of 366 civil servants were used as samples. Results confirm the hypothesized model indicating that the competence has significant effect on job satisfaction and not significant on civil servants performance. Work culture and organizational commitment is a positive and significant effect on job satisfaction and employee performance. Job satisfaction is positive and significant effect on civil servants performance. The mediating role of job satisfaction is significant to explained the effect of organizational commitment on employee performance, but is not significant to explained the effect of work culture, competence on employee performance
\end{abstract}

Keywords - Competence, culture, commitment, job satisfaction, employee performance

Date of Submission: 24-03-2018 Date of Publication: Date: 08-04-2018

\section{BACKGROUND TO RESEARCH}

The use of human Resources to the achievement of goals is the primary function of human resource management. The management of the organization is required to meet the needs of the organization and individual needs so that organizations can use the services of people who work in the organization, develop their skills, to motivate them to improve performance and ensure that they remain committed to a number of activities that are essential to the achievement of organizational goals (Manoj and Das, 2016). Development activities were documented by the Indonesian Government Regulation No. 46 of 2011 on performance appraisal of civil servants (PNS), which aims to ensure the objectives of the construction of a civil servant under the system of job performance and career system which emphasized on work performance system. The system is aimed at encouraging the behavior of civil servants working.

Regional government's working unit (SKPD) in Selayar Islands District is a system that consists of various components that are interconnected with each other in carrying out their respective functions. Organization of regional work units is a system that consists of several components that have their respective roles in accordance with its function. This system involves people working together to achieve common goals. Every organization should have a variety of conditions that must be adhered to by its members, the standard that must be met, and require attention in order to improve quality and employee satisfaction with their jobs. Selayar Island regional government's working unit make serious efforts to develop, improve quality and coordination of all public services in the community at the district level. At this institution officials activity is expected to play a role in creating a pattern of working procedures in carrying out public service activities and be able to overcome all the problems related to competence, work culture and organizational commitment on job satisfaction and performance. But there are still quite a lot happening gap that has not been in line with expectations, there are still some shortcomings pointed out by the officer where the job satisfaction and their performance is low, as shown by their employees who are not punctual when it entered office, delaying the project office, less discipline and cannot take advantage of the good offices and the officials are less concerned with what should be done and it was his responsibility.

The relationship between competence, work culture and organizational commitment to job satisfaction and civil servants performance can be explained by the individual performance theory (Robbins, 2003: 218), that the individual performance of a function of the interaction between ability and motivation and opportunity. The 
process of creation of employee satisfaction is not easy, because the job satisfaction can be created if the variables affecting among other competencies, work culture and organizational commitment to the organization's employees can be accommodated well and accepted by all employees in an organization (Baron and Greenberg, 1990). Organizational performance depends on the performance of the individual or in other words individual performance will contribute to the achievement of the organization (Bernardin, 1993).

Empirical facts give evidence that competence has a significant effect on job satisfaction, the most important dimension in explaining the effect of business competencies and job satisfaction was found in satisfaction with work colleagues and personal satisfaction and the lowest is indicated by the satisfaction on salary dimensions (Kowal and Roztocki, 2015). Results are shown in different studies done several other researchers that competence is a positive and not significant effect on job satisfaction (Zulwan, 2015; Arifin, 2015). Other empirical evidence shows that the competence also affect the performance of the employee, that competence is a significant influence on the individual performance (Luna-arocas and Morley, 2015; Arifin, 2015). The findings were opposed by other researchers, that the competence which is reflected through a core self-evaluations has no significant on employee performance (Song and Chathoth, 2013; Rahardjo, 2014).

The creating of job satisfaction and individual performance is high, not only defined by high or low but the required employee competency contributions from other factors, namely work culture. Previous research findings provide evidence that organizational culture which is reflected through the power distance, uncertainty avoidance, individualism-collectivism, and masculinity-feminity had no significant effect on job satisfaction (Tong et al. 2014). Similar results were shown by Arifin (2015) that organizational culture is not a significant effect on the job satisfaction. Other researchers finding that the organizational culture is positive and significant on job satisfaction (Sukma, 2016; Suwati, 2016). Cause and effect between the variables in turn are built in this study; the influence of culture on employee performance, empirical evidence suggests that organizational culture has a significant effect on the performance of employees (Kamaroellah, 2016; Sappe et al. 2016). The decision was disputed by other researchers, that organizational culture is not a significant influence on the performance of the individual (Arifin, 2015; Daniel and Purwanti, 2015). The other antecedents of employee job satisfaction are an organizational commitment. The previous studies show that the organizational commitment have a significant effect on job satisfaction (Peng et al. 2014; Daniel and Purwanti, 2015; Danaeifar, 2016). Evidence is opposed by other researchers, (Yiing and Ahmed, 2009) that the organizational commitment has a negative and no significant effect on job satisfaction. High commitment not only increases the job satisfaction, but also can improve the individual's performance. The other studies shown, that the organizational commitment have a significant impact on individual performance (Tsai, Cheng, and Chang, 2010; Atmojo, 2012; Pham et al. 2016; Kaynak, et al. 2016). The decision was in contrast to the findings of other researchers, that the organizational commitment is a significant effect on the individual performance, while the continuance commitment has no significant effect on employee performance (Dhurup, Surujlal, and Mutamba, 2016). Other studies have found that all dimensions of the organizational commitment that no significant effect on the manager performance (Dasrita, Tanjung and Basri, 2015).

The high job satisfaction can explain the organization positively, helping colleagues, and make their performance beyond the normal budget, more than the individual who feels satisfied with the level of compliance is high on the call of duty, as individuals eager to repeat their positive experience of work already do (Robbins and Judge, 2009). The findings provide evidence that job satisfaction is positive and significant impact on the individual performance (Atmojo, 2012; Arifin, 2015; Luna-arocas and Morley, 2015; Daniel and Purwanti, 2015). The decision was opposed by other researchers, that job satisfaction is not significant effect on employee performance (Tsai, Cheng, and Chang, 2010; Kanyurhi and Bugandwa, 2016).

\section{Competence}

\section{II.LITERATURE REVIEW}

Competence is the ability or a person's ability to perform various tasks in a job, in which capacity is determined by the ability of the intellectual and physical capabilities (Robbins and Judge, 2007). Another view of the competence mention is made of the unique properties of each individual in the process of interaction with others in a social context, so it is not just limited to knowledge and skill the specific or performance standards expected and the behavior shown. So competencies include attitudes, perceptions and emotions and emphasis on personal interaction and social factors (Antonacopoulou and Gerald, 1996). This study developed a competency measurements received from the Spencer and Spencer (1993) using five measurements are used to analyze the competence is a motive, traits, self-concept, knowledge and skill.

\section{Work culture}

Work culture is a philosophy that is based on a view of life as values into the properties, behavior and driving a culture within a group and is reflected in the attitude to behavior, ideals, views, opinions and actions 
that exist as employment or work. (Gering et al. 2001). Work culture conducted civil servants in Indonesia, referring to government regulations that culture is a way of looking for someone to give meaning to the work or in other words, culture is the way one of the areas that practiced and moral principles held that fosters a strong conviction on the basis of the values that it believes have high spirits and determined to create the best performance (Ministry of State for Administrative Reform, 2002).

Based on the practices, work culture can be interpreted (the Ministry of State for Administrative Reform, 2002), as follows the pattern of values, attitudes, and behaviors, perception of values and the environment, life experiences, habits, and the selection process (accept or reject) the norm in how to interact socially or put himself in the middle of a particular work environment, in the process there are cultural interplay and interdependence, both social and social environment. The study uses these measurements referring (Robbins, 2006: 305) to analyze the work culture, which includes; innovation and risk-taking, attention to detailed, outcome orientation, people orientation, team orientation, aggressiveness, and stability.

\section{Organizational commitment}

There are only one key to the success of the organization depends on the commitment of employees to the organization. Organizational commitment is more than just a formal membership, as cover organizations like the attitude and willingness to work for everything in the interest of the organization. Organization commitment is a condition in which an employee in favor of a particular organization and its goals and its desire to maintain membership in the organization (Robbins and Judge, 2007). The employees also will feel proud to be part of his organization, believe in the goals and values of the organization, it will show the level of performance and productivity of the worker (Sjahruddin and Sudiro, 2013).

The measurements used to analyze the commitment of the organizations in this study refers to the measure used by Mowday et al. (1982) that the employee commitment to the organization, described by five main factors, namely; Identify the individual to the organization, involvement or participation of employees in work activities is crucial in fostering employee commitment, the warmth, affection, and loyalty to the organization, an assessment of their emotional bonding and attachment between the organization and the employee, the willingness to show business. This is apparent through the willingness to work as expected so that the organization can grow and the desire to remain in the organization.

Job satisfaction. Job satisfaction refers to the general attitude of an individual towards his job, so someone with a level of high job satisfaction will show a positive attitude towards work, but if someone is not satisfied with his work will show a negative attitude to work (Robbins, 2006). Job satisfaction involves several fundamental issues among others (Luthans, 2001): (1) job satisfaction cannot be seen, but its existence can only be suspected because of emotional issues affect job satisfaction or response workers from the employment situation faced. (2) Job satisfaction regarding the suitability of the results obtained with the hope of working employees, and (3) Job satisfaction is very closely related to the issue; the work itself, promotional opportunities, salary, supervision and co-workers. Robbins (2003) states there are five factors that drive job satisfaction in this study is used as a measure of employee job satisfaction, namely the work that is mentally challenging, remuneration in kind, working conditions that support, supporting colleagues and management briefing

\section{Employee performance}

Performance of an employee is individualized, because each employee has different skill levels - vary in their job. The management can measure the performance of employees is based on the performance of each employee. Performance is an action, not an event. Action performance itself is made up of many components and is not a result that can be seen at that time as well. Basically, the performance is something that is individualized, because each employee has different levels of ability in doing his job. Performance depends on a combination of skill, effort, and opportunities available. This means that the performance is the result of workers in work for some time, and the emphasis on the results of the work done within a certain time employees (Timpe, 1993).

In relation to the understanding of job performance is often found terms that have almost the same meaning for example: proficiency, merit and productivity. Masi and Cooke (2000), states that proficiency implies broader aspects of reasons, including effort, job performance, initiative, loyalty, leadership potential and morale. Labor productivity is the ratio between input and output. Bernardin and Russell (1993) suggests six key criteria that can be used to measure performance and also used in this study, consisting of quality, quantity, timeliness, cost effective, need for supervisor, and interpersonal import, is the extent to which the employee maintain self-esteem, goodwill and cooperation among colleagues and subordinates.

\section{METHODS}

This study is an exploratory that seeks to find relationships that are relatively new and explanatory research that is done by way of explaining the symptoms caused by an object of study. This study was carried out 
in the Selayar Island District regional government's working unit (SKPD). The population in this study were all civil servants amounted to 4,321 civil servants sampling technique was performed using a proportionated random sampling, so that the total sample of 366 civil servants. AMOS (Analysis of Moment Structural), software vers. 20.0 using to the hypotheses testing

\section{RESULTS}

Respondent characteristics

Respondent characteristics presented in this study as respondents by sex, ages, marital status, educational level and work experiences. For more details the characteristics of the respondents can be described as follows:

Table 1. Respondent characteristics

\begin{tabular}{|l|l|l|l|}
\hline Description & Criteria & Frequency & Percent \\
\hline \multirow{4}{*}{ Gender } & Male & 235 & 64.2 \\
\cline { 2 - 4 } & female & 131 & 35.8 \\
\hline \multirow{5}{*}{ Ages (Years) } & $20-30$ & 11 & 3.0 \\
\cline { 2 - 4 } & $31-40$ & 121 & 33.1 \\
\cline { 2 - 4 } & $41-50$ & 182 & 49.7 \\
\cline { 2 - 4 } & $>51$ & 52 & 14.2 \\
\hline \multirow{5}{*}{ Earital status } & Married & 261 & 71.3 \\
\hline & Single & 105 & 28.7 \\
\hline \multirow{5}{*}{$\begin{array}{l}\text { Work experiences } \\
\text { (Years) }\end{array}$} & Senior high school & 35 & 9,6 \\
\cline { 2 - 4 } & Associate degree & 79 & 21,6 \\
\cline { 2 - 4 } & Bachelor's degree & 164 & 44,8 \\
\cline { 2 - 4 } & Master's degree & 77 & 21 \\
\cline { 2 - 4 } & Doctoral degree & 11 & 3 \\
\hline & $<7$ & 83 & 22,7 \\
\cline { 2 - 4 } & $<14$ & 199 & 54,4 \\
\cline { 2 - 4 } & $<21$ & 59 & 16,1 \\
\cline { 2 - 4 } & $<28$ & 6 & 19 \\
\cline { 2 - 4 } & $>28$ & & \\
\hline
\end{tabular}

\section{Variable description}

This analysis is used to describe the frequency and percentage of any dimension or indicator that build model study of the overall concept. More specifically described as follows:

Table 2. Variable description

\begin{tabular}{|l|l|}
\hline Variable & average value \\
\hline Competence & 4,03 \\
\hline Work culture & 4,00 \\
\hline Organizational commitment & 4,12 \\
\hline Employee job satisfaction & 4,00 \\
\hline Employee job performance & 3,94 \\
\hline
\end{tabular}

\section{Research Instruments Test}

Test results showed that the overall instrument has a correlation value $>0.30$ with a p-value $<0.05$ so that said valid. Then, to test reliability coefficient was performed using Cronbach's alpha. An instrument can be called reliable if the Cronbach's alpha value $>0.60$.

Table 3. Validity and reliability test

\begin{tabular}{|c|c|c|c|c|c|c|}
\hline Variable & Construct & $\begin{array}{l}\text { Correlation } \\
\text { coefficient } \\
\text { value }(\mathrm{r})\end{array}$ & Sig. & Annotation & $\begin{array}{l}\text { Cronbach's } \\
\text { Alpha }\end{array}$ & Annotation \\
\hline Competence & $\begin{array}{l}X_{11} \\
X_{12} \\
X_{13} \\
X_{14} \\
X_{15}\end{array}$ & $\begin{array}{l}0,83 \\
0,77 \\
0,84 \\
0,87 \\
0,65\end{array}$ & $\begin{array}{l}0,00 \\
0,00 \\
0,00 \\
0,00 \\
0,00\end{array}$ & $\begin{array}{l}\text { validity } \\
\text { validity } \\
\text { validity } \\
\text { validity } \\
\text { validity }\end{array}$ & 0,85 & Reliability \\
\hline Work culture & $\begin{array}{l}X_{21} \\
X_{22} \\
X_{23} \\
X_{24} \\
X_{25} \\
X_{26}\end{array}$ & $\begin{array}{l}0,78 \\
0,82 \\
0,76 \\
0,83 \\
0,81 \\
0,85\end{array}$ & $\begin{array}{l}0,00 \\
0,00 \\
0,00 \\
0,00 \\
0,00 \\
0,00\end{array}$ & $\begin{array}{l}\text { validity } \\
\text { validity } \\
\text { validity } \\
\text { validity } \\
\text { validity } \\
\text { validity }\end{array}$ & 0,90 & Reliability \\
\hline
\end{tabular}




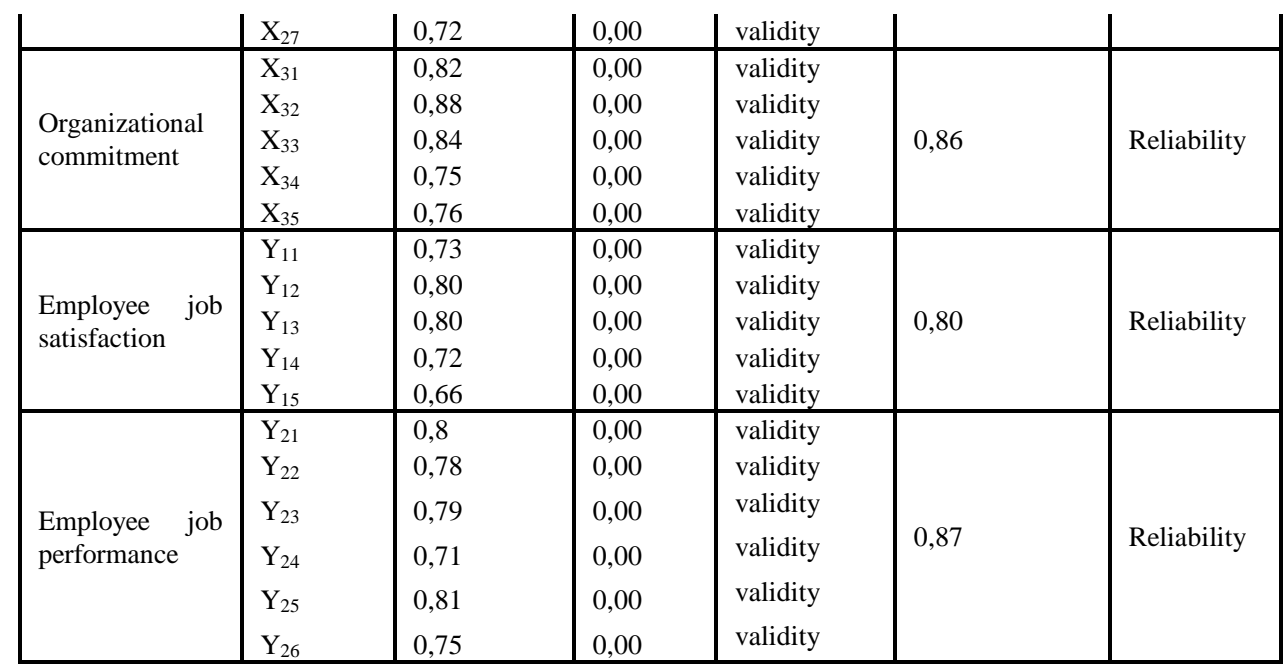

\section{Confirmatory factor analysis}

The results of measurements on the dimensions or indicators of variables that can form a construct or latent variables with confirmatory factor analysis can be explained as follows:

Table 4. Confirmatory factor analysis

\begin{tabular}{|l|l|}
\hline Variable & Loading factor \\
\hline Competence & 0,73 \\
\hline Work culture & 0,76 \\
\hline Organizational commitment & 0,75 \\
\hline Employee job satisfaction & 0,66 \\
\hline Employee job performance & 0,72 \\
\hline
\end{tabular}

The average loading factor of the highest value is shown in the work culture and the lowest obtainable from employee satisfaction.

\section{Structural model}

The exam aims to determine the feasibility of structural model data compatibility with the observation that built and estimated using the standardized regression weights. Model built structures and relationships in the estimation consist of direct and indirect contact refers to the problems and objectives of the study.

Table 5. Goodness of fit

\begin{tabular}{|l|l|l|l|}
\hline index & Cut-off Value & Model results $*$ & Annotation \\
\hline Chi-Square & Expected small & $292,823<(0.05: 259=297,538)$ & Good \\
\hline Probability & $\geq 0.05$ & 0.073 & Good \\
\hline CMIN/DF & $\leq 2.00$ & 1,131 & Good \\
\hline RMSEA & $\leq 0.08$ & 0.019 & Good \\
\hline GFI & $\geq 0.90$ & 0.948 & Good \\
\hline AGFI & $\geq 0.90$ & 0.918 & Good \\
\hline TLI & $\geq 0.95$ & 0.993 & Good \\
\hline CFI & $\geq 0.95$ & 0.995 & Good \\
\hline
\end{tabular}

The model for the study was the test of consistency (goodness of fit tests) the suitability of the model with a cut-off value, because the whole of the eight criteria according to the existing model, the final model were met.

Table 6. Hypothesis testing

\begin{tabular}{|c|c|c|c|c|c|c|c|}
\hline \multicolumn{3}{|l|}{ Variables } & \multirow{2}{*}{ P-value } & \multirow{2}{*}{$\begin{array}{l}\text { Direct } \\
\text { Effect }\end{array}$} & \multirow{2}{*}{$\begin{array}{l}\text { Indirect } \\
\text { Effect }\end{array}$} & \multirow{2}{*}{$\begin{array}{l}\text { Total } \\
\text { Effect }\end{array}$} & \multirow{2}{*}{ Annotation } \\
\hline Exogenous & Intervening & Endogenous & & & & & \\
\hline Competence & & Job satis. & 0,045 & $-0,086$ & 0,000 & $-0,086$ & Significant \\
\hline Work culture & & Job satis. & 0,029 & 0,138 & 0,000 & 0,138 & Significant \\
\hline Org. Comm. & & Job satis. & 0,000 & 0,793 & 0,000 & 0,793 & Significant \\
\hline Competence & & Job perf. & 0,342 & $-0,047$ & 0,000 & $-0,047$ & Insignificant \\
\hline Work Culture & & Job perf. & 0,046 & 0,139 & 0,000 & 0,139 & Significant \\
\hline Org. Comm. & & Job perf. & 0,001 & 0,370 & 0,000 & 0,370 & Significant \\
\hline
\end{tabular}


The Antecedents, Consequences, And Mediating Role Of Job Satisfaction: Perception And Relevance Among

\begin{tabular}{|l|l|l|l|l|l|l|l|}
\hline Job satis. & & Job perf. & 0,000 & 0,343 & 0,000 & 0,343 & Significant \\
\hline Competence & Job satis. & Job perf. & 0,079 & $-0,047$ & $-0,030$ & -0.077 & Insignificant \\
\hline Work Culture & Job satis. & Job perf. & 0,062 & 0,139 & 0,047 & 0.186 & Insignificant \\
\hline Org. Comm. & Job satis. & Job perf. & 0,001 & 0,370 & 0,272 & 0.642 & Significant \\
\hline
\end{tabular}

\section{Competence effect on job satisfaction}

The Islamic view of competence related to job satisfaction can be explained in QS. An - Nahl: 43, which means: and we did not send before you any but men to whom we revealed to them; then ask those who have the knowledge, if you do not know. The effect of competence on job satisfaction can be demonstrated by the standardized regression weight estimate of -0.086 with a negative direction. Influence coefficients are negative, have the meaning that the competency of employees is relatively low, resulting in a decrease in employee job satisfaction, but it can be evidenced by the critical ratio $=-2.008<2.00$ and the probability of $0,045<\alpha=0.05$. The test results prove that the first hypothesis, the competence of a negative and significant effect on employees job satisfaction, so the hypothesis $1\left(\mathrm{H}_{1}\right)$ proposed that competence positive and significant effect on job satisfaction.

Because employees do not have enough skills and appropriate to carry out the duties and responsibilities both physically and mentally so although not optimal but in practice proven to improve employee satisfaction through the ability of leadership in directing subordinates to work until the completion of the work not having problems which means in turn can be completed on some results of this study support the findings Kowal and Roztocki (2015) business competencies positive and significant impact on job satisfaction are characterized by the satisfaction of co-workers, supervision and self-employed. Rejecting the findings of other researchers that competence and not significant positive effect on job satisfaction (Zulwan, 2015; Arifin, 2015).

\section{Work culture effect on job satisfaction}

The Islamic view on cultural work related to job satisfaction can be explained in the QS. Ar-Rad: 11 which Means: For him are angels in succession, before and behind him: They guard him by command of Allah. Allah does not change a people's condition unless they change what is in themselves. And when Allah intends evil to a people, there is none that can avert it; and it, nor have they a defender beside Him. The effect of work culture on job satisfaction can be evidenced by the standardized regression weight estimate of 0,138 with positive direction. The coefficient is a positive, a sense that all this work culture growing niche to show good officers, the resulting in an increase in the satisfaction of employees, but it can be evidenced by the critical ratio $=2.180>2.00$ and the probability of $0,029<\alpha=0: 05$. The test results of prove that the second hypothesis, the work culture positive and significant impact on job satisfaction of employees, so the hypothesis $2\left(\mathrm{H}_{2}\right)$ proposed that the work culture positive and significant impact on job satisfaction proved otherwise received and supported by empirical facts.

This condition is the caused due to an employee in the work always be ambitious and not Easily give up any difficult, obstacles or barriers that they face in their work so as to Contribute to the desire of employees to get rewarded for Reviews their work, as evidenced by promotion implemented a in a fair and transparent manner and the provision of incentives for fair and transparent to employees so that employees show a sense of satisfaction in work. The results of this study support the work culture theory (Robbins, 2006: 305) that the work culture in the organization is a system of values held and Carried out by members of the organization, so that such a case can extinguishing Reviews those organization with other. Supports previous research findings that culture is applied to the organization to support the work so that positive and significant impact on job satisfaction (Arifin, 2015. Sukma, 2016; Suwati, 2016; Kamaroellah, 2016). Rejecting the findings of other researchers that work culture is reflected not significant influence on job satisfaction, as reflected through the works itself, payment, promotion and satisfaction with supervision and satisfaction co-workers (Tong etal. 2014; Daniel and Purwanti, 2015).

\section{Organizational commitment on job satisfaction}

Work commitment is based on the belief that the work commitment has implications, not only on the employee and the organization, but also to the community whole. Employee work commitment is more likely to receive extrinsic rewards such as income and psychological associated with membership in the organization as the embodiment of a sense of satisfaction of employees of the organization. Islam views related organizational commitment and job satisfaction can be explained in the QS. As-Shu'ara: 87-89, which means (87) and Thou despise me on the day they are raised, (88). (i.e.) on the property and the children of men are useless, (89). Except those facing God with a clean heart. The effect of organizational commitment on job satisfaction can be evidenced by value the standardized regression weight estimate of 0.793 with a positive direction. Influence coefficient is positive, meaning that the high organizational commitment resulting improving employee job 
satisfaction, but it can be evidenced by the value critical ratio $=10.014>2.00$ and a probability value of $0.000<\alpha$ $=0.05$. The results of third hypothesis testing proved that, organizational commitment positive and significant effect on employees job satisfaction, so the hypothesis $3\left(\mathrm{H}_{3}\right)$ proposed that organizational commitment positive and significant effect on job satisfaction convicted accepted and supported by empirical facts.

Factors that cause a positive and significant effect of organizational commitment to employee satisfaction due because of the high level of trust of employees in the organization and the level of involvement and participation of employees as evidenced by the willingness of employees to be prepared for when it is needed and at the opposite so as to give a significant effect on the willingness of colleagues working to assist the completion of the task of other colleagues and the willingness of employers to continue discussions with employees regarding the completion of the work results support the organizational commitment theory, that the organizational commitment refers to identifying employee goals with organizational goals, willingness to mobilize all abilities for the benefit of the organization and its ties to remain be part of the organization (Mowday et al. 1982). Supports the findings of previous studies that a significant effect of organizational commitment on job satisfaction (Peng et al. 2014; Daniel and Purwanti, 2015; Danaeifar, 2016). Rejecting the findings Yiing and Ahmed (2009) found insignificant effect of organizational commitment on job satisfaction.

\section{Effects of competence on employee performance}

Quality of human resources (HR) is one of the factors to improve the organizational performance. The Islamic view of the of the individual performance shown in QS. Al-Ahqaaf: 19. Meaning: and for each of their degrees according to what they have done and that God will suffice for them (children) their jobs they are not harmed. Effects of competence on employee performance can be demonstrated byte value standardized regression weight estimate of $-0,047$ with negative direction. Influence coefficient is negative, meaning that the employees competency is relatively low, resulting in a decline in the employees performance, but it can be evidenced by the value critical ratio $=-0.951<2.00$ and a probability value of $0.342>\alpha=0.05$. The test results prove that the fourth hypothesis, competence negative and insignificant effect on employees performance, so the hypothesis $4\left(\mathrm{H}_{4}\right)$ proposed that competence positive and significant effect on employee performance be rejected or not supported by empirical facts.

Factors causing competence negative and significant effect employee performance due to the low expertise of employees in helping to resolve other employee work and not to an employee desire to assist in the completion of the work due to the limited expertise of employees in work. Such condition adversely affects the employee's inability to use and utilize the financial resources, technology, materials to be maximized in order to obtain the highest work. The results of this study support the statement Mowday et al. (1982) that the commitment of the organization does not happen very easily and quickly. But undergo a process of gradual and long enough. Supports previous research findings, that the management talent (competence) does not significantly influence the performance of the work (Song and Chathoth, 2013; Rahardjo, 2014; Luna-arocas and Morley, 2015) Rejecting the findings, the competence significant effect on employee's performance (Arifin, 2015).

\section{Effect of work culture on employee performance}

Work culture is a manifestation of the success of the work, rooted in values that are owned and behaviors become habits. Those values originated from the customs, religion, norms and rules that into a belief become a habit in the workplace or organizational behavior. Cultural relevance to the performance in perspective of Islam is explained in QS. At-Tawbah verse 105 which means: and Say: Work you, and then Allah and His messenger and the believers will see your work it and you will be returned to (Allah) knows will be the unseen and the real, and preached unto you what ye used to do. The effect of work culture on employee performance can be evidenced by the value of standardized regression weight estimate of 0,139 with a positive direction. Influence coefficient is positive, meaning that the work culture tend to either give a significant effect on improving employee performance, but it can be evidenced by the value critical ratio $=1.991<2.00$ and a probability value of $0.046<\alpha=0.05$. The results of fifth hypothesis testing proved that, work culture positive and significant effect on employees performance, so the hypothesis $5\left(\mathrm{H}_{5}\right)$ proposed that the work culture positive and significant effect on employee performance convicted accepted and supported by empirical facts.

Factors causing the positive and significant influence of work culture on employee performance due to the employee is able to show aggressiveness and competitive work so the real impact on the increase in the employees performance resulting from employee is able to carry out his work as a whole, an employee has a work speed as expected so that they can finish the job in accordance with the targets set. Work culture positive and significant effect on the performance of employees (Kamaroellah, 2016; Sappe et al. 2016). Rejecting another finding, work culture is positive and insignificant effect on individual performance (Arifin, 2015; Daniel and Purwanti, 2015). 


\section{Effect of organizational commitment on employee performance}

Employees who are committed will feel proud to be part of the organization, believe in the goals and values of the organization, it will show the level of employee performance and productivity of the (Sjahruddin and Sudiro, 2013). The effect of organizational commitment on employee performance can be demonstrated by the value standardized regression weight estimate of 0.370 with a positive direction. Influence coefficient is positive, meaning that the high organizational commitment resulted in increased employee performance, but it can be evidenced by the critical ratio value $=3.205>2.00$ and a probability value of $0.001<\alpha=0.05$, The results of sixth hypothesis testing proved that organizational commitment positive and significant effect on employees performance, so the hypothesis $6\left(\mathrm{H}_{6}\right)$ proposed that organizational commitment positive and significant effect on employee performance convicted accepted and supported by empirical facts.

Factors that cause a positive and significant effect of organizational commitment to employee performance due to the high level of involvement and participation of employees in the organization and willingness to always be ready when needed, and the similarities between the value of personally owned by employees with values - values that apply in the organization resulted in a high concern for employees to regional government's working unit thus providing a significant effect on the ability of employees to work properly results of this study support previous research that organizational commitment positive and significant effect on employee performance (Tsai, Cheng and Chang, 2010; Atmojo, 2012; Sappe et al. 2016; Pham et al., 2016; Kaynak et al. 2016). Rejecting another finding, that proves the all dimensions of organizational commitment are not significant on manager's performance (Dasrita, Tanjung and Basri, 2015).

\section{Job satisfaction on performance}

Job satisfaction refers to the general attitude of an individual towards his job, so someone with a level of high job satisfaction will show a positive attitude towards work, otherwise if a person is not satisfied with the work will show a negative attitude towards work (Robbins, 2006). The linkage between job satisfactions on performance is described in the QS. Al Araf: 39 which Mean, and said those who entered earlier between them to the people who entered afterwards: "You do not have the slightest excess on us, and then taste the torment because of what you have done".

The effect of job satisfaction on employee performance can be demonstrated by value standardized regression weight estimate of 0.343 with a positive direction. Influence coefficient is positive, meaning that high job satisfaction resulting increased employees performance, but it can be evidenced by the value critical ratio = $3.644>2.00$ and a probability value of $0.000<\alpha=0.05$. The test results prove the hypothesis seventh that job satisfaction is positive and significant effect on the performance of employees, so the hypothesis $7\left(\mathrm{H}_{7}\right)$ proposed that job satisfaction is positive and significant effect on employee performance convicted accepted and supported by empirical facts.

Factors that cause a positive and significant effect of job satisfaction on employee performance due to a work environment that is managed in a way to produce a comfortable working environment and safe making it easier for employees in completing the work and the ability of employees to minimize errors or mistakes in the work as well as the establishment of a harmonious relationship between fellow employees as well as with the leadership of this study support the discrepancy theory developer by Locke (1969) that measures the satisfaction can be done by calculating the difference between what should have been the fact that the perceived employee. The previous studies proved that job satisfaction have a significant effect on employee performance (Atmojo, 2012; Arifin, 2015; Luna-arocas and Morley, 2015; Daniel and Purwanti, 2015; Kamaroellah, 2016). Rejecting the findings, that job satisfaction is not significant on the performance (Kanyurhi and Bugandwa, 2016; Tsai, Cheng and Chang, 2010).

\section{Competence on employee's performance: The mediating role of job satisfaction}

Sobel test results using the approach of Baron and Kenny (1986) provide evidence that the value of the indirect effect of -0.025 and the value of the standardized indirect effect of -0.029 with p-value $0.079>0.05$. The mediating role of job satisfaction in analyzing the effect of competence on employee performance is negative and insignificant. The cause of the negative and significant effect of competence on the performance of employees through the job satisfaction due to the direct knowledge and expertise and capabilities of employees is not optimal in the creation process of employee performance, look at the placement of employees in occupations that do not match the background skills and knowledge possessed, although with the support of incentives and adequate honorarium making it difficult for employees to be able to produce quality work. The results of this study support the findings of Luna-arocas and Morley (2015) that the management talent (competence) is not significant influence on performance through job satisfaction act as a mediator. Rejecting the findings by Arifin (2015) that job satisfaction proved to be a full mediation in explaining the influence of organizational culture on teacher performance. 
Work culture on employee's performance: The mediating role of job satisfaction

Sobel test results using the approach of Baron and Kenny (1986) provide evidence that the value of the indirect effect amounted to 0.051 and the value of the standardized indirect effect amounted to 0,047 with pvalue $0.062>0.05$. The mediating role of job satisfaction in analyzing the influence of work culture on employee performance is positive but not significant.

The cause of the positive and not significant influence workplace culture on employee performance through job satisfaction caused directly in the daily activity workplace employees possess pro-active to know everything concerning his work and not easily discouraged, as difficult as the work of employees keep working. This is regardless of the motives underlying the employee in completing the task, that with the completion of the task they have done the employee an incentive and emoluments other and, if deemed their work is always so much better every time, the employee is given the opportunity to participate in the promotion in accordance with per statutory regulations applicable.

In addition an employee is able to produce quality work and results of their work or free of errors, so it is not necessary to have the support means on the availability of the necessary work which can be used employees in completing the work. The results support the findings by Arifin (2015); Kamaroellah (2016) that job satisfaction is not proven as mediating role in explaining the effect of work culture on performance. Rejecting findings by Abdulrani et al. (2014) that the organizational culture is positive and significant on performance, job satisfaction it's not a mediating variable in analyzing the effect of culture on performance.

Organizational commitment on employee's performance: The mediating role of job satisfaction

Sobel test results using the approach of Baron and Kenny (1986) provide evidence that the value of the indirect effect amounted to 0.279 and the value of the standardized indirect effect of 0.272 with a p-value of $0.001>0.05$. The mediating role of job satisfaction in analyzing the effect of organizational commitment to employee performance is positive and significant. The cause of the positive and significant effect of organizational commitment to employee performance through job satisfaction is directly due to the degree of involvement or participation of employees in the organization is high and employees availability are always ready when needed or on the opposite. The conditions created by the similarity between personal values held employees with prevailing values in the organization and a sense of pride that the employees are part of regional government's working unit and high caring attitude towards Selayar Island district regional government's working unit. The results of this study support the results Carmeli and Freund (2004) that job satisfaction is not proven as a mediating variable in analyzing the effect of commitment on performance.

\section{CONCLUSION}

Competence is significant effect on civil servants job satisfaction, due to the civil servants not have sufficient and appropriate skills to carry out their duties and responsibilities, both physically and mentally so but in practice proven to increase civil servants job satisfaction. Work culture positive and significant impact on civil servants job satisfaction, employee well always be ambitious and not easily give up any difficult obstacles or barriers they face in their work so that they can make a meaningful contribution to the desire of civil servants to obtain a just retribution for their work.

The high organizational commitment proven to increase civil servants job satisfaction, a high level of trust of civil servants in the organization and the level of civil servants involvement in the work is able to give a significant effect on the willingness of colleagues to assist the completion of the task of other colleagues and the willingness of employers to continue discussions with employees regarding the completion of the work. Civil servants competency is relatively low and is unable to improve civil servants performance, due to the low inability of civil servants to use and utilize the financial resources, technology, materials to be maximized in order to obtain the highest work. Good work culture a significant impact on improving the civil servants performance, that civil servants carry out his work as a whole and the employee has a work speed as expected so as to complete the work in accordance with the targets set.

The high organizational commitment which resulted in increased civil servants performance due to concerns for civil servants to regional government's working unit thus providing a significant effect on the ability of civil servants to work properly. High job satisfaction and perceived civil servants is currently a trigger for a high civil servants performance due to employees to minimize errors or mistakes in work and harmonious relations among employees as well as with the leaders. Job satisfaction does not provide a meaningful influence in analyzing the effect of competence on civil servants performance. The mediating role of job satisfaction in working culture analyze the effect on civil servants performance is positive but not significant. The mediating role of job satisfaction in analyzing the effect of competence on civil servants performance is positive and significant. 


\section{REFERENCES}

[1]. Abdulrani, S., Abdullah, A., and Matriadi, F. (2014). The influence of empowerment, self-efficacy and organizational culture on employee performance PT. Surya Madistrindo Lhokseumawe Branch with job satisfaction as an intervening variable. Journal of Economics, Management and Accounting, 4 (1), 26-37.

[2]. Antonacopoulou, E. P., and FitzGerald, L. (1996). Reframing competency in management development. Human Resource Management Journal, 6(1), 27-48

[3]. Arifin, H. M. (2015). The Influence of Competence, Motivation, and Organisational Culture to High School Teacher Job Satisfaction and Performance, 8(1), 38-45. http://doi.org/10.5539/ies.v8n1p38

[4]. Atmojo, M. (2015). The influence of transformational leadership on job satisfaction, organizational commitment, and employee performance. International research journal of business studies, 5(2).

[5]. Baron, R. M., \& Kenny, D. A. (1986). The moderator-mediator variable distinction in social psychological research: Conceptual, strategic, and statistical considerations. Journal of personality and social psychology, 51(6), 1173.

[6]. Baron, R.A., and Greenberg, J. (1990). Behavior in organizations, 3rd ed. Boston, MA: Allyn \& Bacon (A Division of Simon \& Schuster, Inc.)

[7]. Bernardin, J. Russell. (1993). Human Resource Management, Mc Graw-Hill International Edition

[8]. Carmeli, A., \& Freund, A. (2003). Work commitment, job satisfaction, and job performance: An empirical investigation. International Journal of Organization Theory \& Behavior, 7(3), 289-309.

[9]. Danaeifar, I. (2016). The Relationship between Organizational Commitment and Quality of Work Life and Job Satisfaction of the Employees of the Department of Telecommunications of Behbahan, 1725-1737.

[10]. Daniel, F. and Furwanti, A. (2015). The impact of organizational culture and job satisfaction to organizational commitment and employees job performance (An empirical study at A University in Tangerang). Conference Paper · October

[11]. Dasrita, T., Tanjung, AR, and Basri, M. (2015). Relations with the Performance Measurement System Managerial Performance: The Role of Procedural Fairness, Clarity of Roles, and Organizational Commitment as a mediating variable 10,195-210

[12]. Dhurup, M., Surujlal, J., and Mutamba, D. (2016). Finding Synergic Relationships in Teamwork, Organizational Commitment and Job Satisfaction: A Case Study of a Construction Organization in a Developing Country. Procedia Economics and Finance, 35(October 2015), 485-492. http://doi.org/10.1016/S2212-5671(16)00060-5

[13]. Gering, Supriyadi and Triguno. (2001). Work Culture Government Organization. Jakarta. State Administration

[14]. Kamaroellah, R. A. (2016). Work Environment and Cultural Influence on Job Satisfaction and Organizational Work Motivation And Performance Echelon III and IV At the Regional Office of Pamekasan. Discourse EQUILIBERIUM, 2(2)

[15]. Kanyurhi, E. B., and Bugandwa Mugu Akonkwa, D. (2016). Internal marketing, employee job satisfaction, and perceived organizational performance in microfinance institutions. International Journal of Bank Marketing, 34(5). ISO 690

[16]. Kaynak, R., Toklu, A. T., Elci, M., and Toklu, İ. T. (2016). Effects of Occupational Health and Safety Practices on Organizational Commitment, Work Alienation, and Job Performance: Using the PLS-SEM Approach, 11(5), 146-166. http://doi.org/10.5539/ijbm.v11n5p146

[17]. Kowal, J., and Roztocki, N. (2015). Job satisfaction of IT professionals in Poland: does business competence matter? Journal of Business Economics and Management, 16(5), 995-1012. http://doi.org/10.3846/16111699.2014.924988

[18]. Locke, E. A. (1969). What is job satisfaction?. Organizational behavior and human performance, 4(4), 309-336.

[19]. Luna-arocas, R., and Morley, M. J. (2015). Talent management, talent mindset competency and job performance: the mediating role of job satisfaction, $9(1), 28-51$.

[20]. Luthans, Fred. (2001). Organizational Behavior, ninth edition. New york :McGraw Hill

[21]. Manoj, N., and Das, V. T. (2016). Management Human Resource Management Practices Impact on Employee Job Satisfaction in The Public Sector Undertakings - An Empirical Study Guntur, (April), 209-212.

[22]. Masi, R. J., and Cooke, R. A. (2000). Effects of transformational leadership on subordinate motivation, empowering norms, and organizational productivity. International Journal of Organizational Analysis, 8(1), 16-47.http://dx.doi.org/10.1108/eb028909

[23]. Ministry of State for Administrative Reform. (2002). Guidelines for Administrative Development Work Culture. Jakarta. Indonesia

[24]. Mowday R., Porter L. and Steers R. (1982). Employee organization Linkages: The Psychology of Commitment, Absenteeism, and Turnover, Academic Press, New York, NY

[25]. Peng, J., Li, D., Zhang, Z., Tian, Y., Miao, D., Xiao, W., and Zhang, J. (2014). How can core self-evaluations influence job burnout? The key roles of organizational commitment and job satisfaction. Journal of Health Psychology, (169), 1359105314521478-. http://doi.org/10.1177/1359105314521478

[26]. Pham, T. K., Pham, C. H., and Pham, L. (2016). Top Management Support , Organizational Learning , Innovative Behavior , Employee Commitment and Organizational Performance of Manufacturing Companies in Hai Phong, 7(3). http://doi.org/10.5430/ijfr.v7n3p54

[27]. Rahardjo, S. (2014). The Effect of Competence, Leadership and Work Environment Towards Motivation and its Impact on the Performance of Teacher of Elementary School in Surakarta City, Central JAVA, Indonesia. International Journal of Advanced Research in Management and Social Sciences, 3(6), 59-74. Retrieved from http://www.garph.co.uk/IJARMSS/June2014/7.pdf

[28]. Republic of Indonesia. (2011). Government Regulation No. 46 of 2011 on the performance appraisal of civil servants (PNS).

[29]. Robbins, P. Stephen and Timothy, A Judge. (2009). Perilaku Organisasi Jilid I dan II Terjemahan, Edisi 12, Jakarta: Penerbit Salemba Empat

[30]. Robbins, S. P., and Judge, T. A. (2007). Organizational behaviour. New Jersey: Pearson Education Inc

[31]. Robbins, Stephen P. (2003). Organizational Behavior.Canada: Prentice Hall

[32]. Robbins, Stephen P. (2006). Organizational Behavior, Edition Translation, Jakarta: PT Prenhalindo

[33]. Sappe, S., Rante, Y., Tuhumena, R., and Bharanti, B. E. (2016). Effect of Leadership on Employee's Performance Mediated by Cultural Organization, Work Commitment and Motivation. Journal of Economics and Behavioral Studies, 8(2), 101-107

[34]. Sjahruddin, H., and Sudiro, A. (2013). Personality Effect on Organizational Citizenship Behavior (OCB): Trust in Manager and Organizational Commitment Mediator of Organizational Justice in Makassar City Hospitals (Indonesia). European Journal of Business and Management, 5(9), 95-104.

[35]. Song, Z., and Chathoth, P. K. (2013). Core self-evaluations and job performance: The mediating role of employees' assimilationspecific adjustment factors. International Journal of Hospitality Management, 33(1), $240-249$. http://doi.org/10.1016/j.ijhm.2012.08.009

[36]. Spencer L.M and Spencer S.M. (1993). Competence at Work: Models for Superior Performance. New York: John Wiley \& Sons, Inc. 
[37]. Sukma, N., Haryono, A. T., and Wulan, H. S. (2016). Analysis of The Influence of personality characteristics, organizational culture and quality of work life on employee performance and job satisfaction as an intervening variable. Journal of Management, 2(2).

[38]. Suwati, S., Minarsih, M. M., and Gagah, E. (2016). Influence of motivation work, career development and cultural organization on the job satisfaction and implications on the performance of employees (Case on BABINMINVETCADDAM IV/Diponegoro). Journal of Management, 2(2).

[39]. Timpe, A. Dale. (1993). Performance, translation Sofyan Cikmat, Jakarta: PT. Gramedia Asri Media.

[40]. Tong, C., Wah Tak, W. I., and Wong, A. (2014). The Impact of Knowledge Sharing on the Relationship between Organizational Culture and Job Satisfaction: the Perception of Information Communication and Technology (ICT) Practitioners in Hong Kong. International Journal of Human Resource Studies, 3(1), 9. http://doi.org/10.5296/ijhrs.v3i1.3112

[41]. Tsai, M. C., Cheng, C. C., and Chang, Y. Y. (2010). Drivers of hospitality industry employees' job satisfaction, organizational commitment and job performance. African Journal of Business Management, 4(18), 4118-4134

[42]. Vroom, V.H. (1964). Work and motivation. Oxford, England: Wiley.

[43]. Yiing, L. H., and Ahmed, K. Z. Bin. (2009). The moderating effects of organizational culture on the relationships between leadership behaviour and organizational commitment and between organizational commitment and job satisfaction and performance". Leadership \& Organization Development, 30(1), 53 - 86. http://doi.org/10.1108/01437730910927106

[44]. Zulwan, A. (2015). The Effect Of Work Stress, Competence And Communication On Job Satisfaction In Improving The Performance Of Employees At The Department Of Agriculture And Forestry Plantations Boyolali. eAbstract Excellent, 2(1)

Tajuddin Makka." The Antecedents, Consequences, And Mediating Role Of Job Satisfaction: Perception And Relevance Among Civil Servants In Regional Government's Working Unit Selayar Islands District." The International Journal of Engineering and Science (IJES) 7.4 (2018): 13-23 